Jurnal Geocelebes Vol. 3 No. 2, Oktober 2019, 111 - 115

\title{
INTERPRETASI STRUKTUR PERLAPISAN TANAH MENGGUNAKAN METODE GEOLISTRIK RESISTIVITAS
}

\author{
Erfan*, Syamsuddin, Arum Wahyuni, Jumatriani, St. Syakirah, Illa \\ Departemen Geofisika FMIPA Universitas Hasanuddin, Makassar \\ *Penulis koresponden. Alamat email: erfan.syamsudin@unhas.ac.id
}

\begin{abstract}
Abstrak
Metode geolistrik resistivitas merupakan salah satu metode geofisika dengan uji tidak merusak (nondestructive test) sifat fisik asli tanah atau batuan. Penginjeksian arus listrik pada permukaan tanah merupakan ciri dari metode ini, yang kemudian diikuti dengan pembacaan beda potensial melalui sepasang elektroda lainnya. Konfigurasi elektroda arus dan potensial dikondisikan berdasarkan konfigurasi Werner-Schlumberger. Akuisisi data diperoleh dari 3 lokasi yang berbeda untuk memperoleh pemahaman tentang struktur bawah permukaan yang lebih baik. Interpretasi terhadap material lapisan tanah dilakukan dengan memanfaatkan penampang resistivitas setelah dilakukan pengolahan data menggunakan software Res2dinv. Hasil yang diperoleh adalah variasi nilai resistivitas dan interpretasi lapisan tanah untuk masing masing lokasi pengambilan data..
\end{abstract}

Kata Kunci: Lapisan tanah; Resistivitas; Res2dinv.

\begin{abstract}
The resistivity method is a geophysical method with a non-destructive test of the original physical properties of soil or rock. The injection of an electric current at the ground surface is a feature of this method, which is then followed by the reading of the potential difference by means of another pair of electrodes. The current and potential electrode configurations are conditioned on the WernerSchlumberger configuration. Data acquisition was obtained from 3 different locations to get a better understanding of subsurface structures. Interpretation of soil material is carried out by utilizing a resistivity cross section after processing data using Res2dinv software. The results obtained are variations in resistivity values and soil layer interpretation for each data collection.
\end{abstract}

Keywords: Soil layers; Resistivity; Res2dinv.

\section{Pendahuluan}

Geofisika merupakan ilmu yang mempelajari tentang tanah dan batuan melalui sifat sifat fisiknya. Telaah tentang struktur bawah permukaan dengan memanfaatkan hukum hukum ilmu fisika, serta pemodelan fisik dan matematis untuk mengetahui kandungan mineral dan struktur lapisan di bawah permukaan bumi merupakan ciri dasar dari ilmu ini.
Pengukuran - pengukuran lapangan dilakukan dengan menggunakan metode geofisika tertentu, yang kemudian dapat dilanjutkan melalui analisa laboratorium. Kegiatan eksplorasi geofisika dapat memanfaatkan hukum - hukum fisika, serta pemodelan matematika bergantung pada jenis metode geofisika yang akan diterapkan dan sumber energinya baik pasif ataupun aktif. Tujuan akhir dari kegiatan eksplorasi adalah peningkatan 
perekonomian dan kelangsungan kehidupan manusia yang lebih baik.

Penggunaan metode - metode geofisika dapat saja diintegrasikan untuk suatu kasus atau obyek penelitian tertentu, dalam rangka memperoleh hasil interpretasi yang lebih baik. Akan tetapi, target penelitian yang akan dituju memungkinkan penggunaan metode geofisika diefisienkan, sebagai contoh, untuk tujuan pencarian sumber - sumber mineral tertentu dapat digunakan metode geomagnet dan GPR (Ground Penetrating Radar) dengan sumber gelombang elektromagnet. Pada target penelitian lain, misalnya untuk mengetahui struktur dan jenis tanah dan batuan dan daya dukung, dapat memanfaatkan metode geolistrik dan seismik.

Penelitian ini difokuskan pada pemanfaatan metode geofisika yang sifatnya tidak merusak (non-destructive) sifat fisik tanah atau batuan. Metode geofisika yang akan dimanfaatkan pada penelitian ini adalah metode geolistrik resistivitas, Penginjeksian arus listrik di permukaan tanah melalui sepasang elektroda arus, yang kemudian dilanjutkan dengan pembacaan beda potensial listrik melalui sepasang elektroda potensial merupakan ciri dasar dari metode ini. Sifat kelistrikan material bumi, kemudian dapat diungkap melalui metode ini. Kelebihan dari metode ini adalah efisiensi pada akuisisi data dan tanpa pengeboran yang cenderung akan merusak sifat asli tanah dan batuan. Akusisi data dilakukan pada tiga tempat yang berbeda untuk dianalisis jenis tanah dan batuan dari penampang resistivitas yang diperoleh.

\section{Metode Penelitian}

Reynold (1997) menjelaskan bahwa variasi resistivitas lapisan tanah di bawah permukaan dapat diungkap dengan mengetahui beda potensial listriknya, setelah melalui injeksi arus listrik. Pengukuran dilakukan dengan menggunakan sepasang elektroda arus dan potensial yang kemudian memungkinkan pembacaan parameter kelistrikan tanah dan batuan dapat diperoleh.

Dasar perhitungan dilakukan melalui hukum hukum Ohm (1), menghubungkan antara arus listrik yang mengalir pada sebuah material konduktif dengan tegangan listrik yang dihasilkan. Hubungan secara matematis dari hukum tersebut dapat ditulis:

$$
\Delta V=I R
$$

dengan:

$\Delta \mathrm{V}=$ Beda potensial (Volt),

$\mathrm{I}=$ Arus listrik (Ampere)

$\mathrm{R}=$ Resistansi (Ohm).

Selanjutnya, Kearey (2002) membedakan pengertian sifat hambatan (resistansi) yang dimiliki oleh arus listrik ketika mengalir melewati suatu material dengan resistivitas. Dalam ungkapannya, resistivitas listrik tidak hanya dipengaruhi oleh jenis material, akan tetapi juga dipengaruhi oleh bentuk geometri bahan yang dilewati arus listrik. Dengan demikian, bentuk geometri dan tahanan listrik suatu bahan merupakan parameter penting di dalam menentukan nilai resistivitas suatu material, dengan hubungan matematis seperti berikut:

$$
R=\rho \frac{L}{A}
$$

dengan:

$\mathrm{R}=$ Resistansi $(\mathrm{Ohm})$

$\rho=$ Resistivitas (Ohm.m)

$\mathrm{L}=$ Perubahan panjang penampang $(\mathrm{m})$

$\mathrm{A}=$ Luas permukaan penampang $\left(\mathrm{m}^{2}\right)$

Subtitusi persamaan (1) ke persamaan (2) menghasilkan hubungan matematis seperti:

$$
\rho=\frac{A}{L} \frac{\Delta V}{I}
$$

Resistivitas $(\rho)$ yang sesungguhnya dari suatu material dapat diperoleh dengan memanfaatkan persamaan (3). Akan tetapi, istilah resistivitas semu (apparent 
resistivity) $\left(\rho_{a}\right)$ muncul kemudian setelah didapatkan bahwa pada kenyataannya bumi atau lapisan di bawah permukaan merupakan material yang tidak homogen. Wijaya (2009) mengungkapkan bahwa nilai resistivitas yang terbaca dalam pengukuran geolistrik tahanan jenis adalah fiktif homogen yang setara dengan tinjauan bahwa struktu di bawah permukaan bumi bumi adalah berlapis.

Formulasi kemudian berubah dengan memperhatikan faktor resistivitas dari nilai sesungguhnya, melalui hubungan berikut:

$$
\rho_{a}=k \frac{\Delta V}{I}
$$

Faktor k pada persamaan (4) berhubungan dengan bentuk geometri material dan konfigurasi elektroda arus dan potensial yang digunakan dalam penelitian menggunakan metode geolistrik tahanan jenis. Salah satu konfigurasi yang sering digunakan dalam metode geolistrik adalah gabungan antara metode Wenner dan Schlumberger. Konfigurasi ini sensitif terhadap perubahan lateral material bumi. Faktor geometri (k) mengalami reformulasi dengan konfigurasi ini menjadi (Loke, 2004):

$$
k=\pi n(n+1) a
$$

Simbol "a" pada persamaan (5) adalah jarak antara elektroda potensial, sedangkan $n$ adalah jumlah pasangan elektroda arus listrik. Dengan demikian persamaan (4) dikembangkan menjadi persamaan (6) setelah disubtitusi nilai $\mathrm{k}$ pada persamaan (5) (Loke, 2004):

$$
\rho_{a}=\pi n(n+1) a \frac{\Delta V}{I}
$$

Nilai resistivitas fiktif kemudian dapat dihitung untuk setiap kedalaman.

Berikut adalah tampilan tabel (Tabel 1) jenis material dengan rentang nilai resistivitasnya. Tabel ini digunakan untuk memperoleh citra nilai resistivitas setelah dilakukan pengukuran resistivitas yang diimplementasikan ke dalam software Res2dinv.

Tabel 1. Nilai resistivitas batuan (Telford dkk., 1990)

\begin{tabular}{ll}
\hline \multicolumn{1}{c}{ Material } & Resistivitas (\$m) \\
\hline Udara ( Air) & $\sim$ \\
\hline Pirit ( Pyrite) & $0.01-100$ \\
\hline Kwarsa ( Quartz) & $500-800000$ \\
\hline Kalsit ( Calcite) & $1 \times 10^{12}-1 \times 10^{13}$ \\
\hline Garam Batu ( Rock salt) & $30-1 \times 10^{13}$ \\
\hline Granit ( Granite) & $200-10000$ \\
\hline Andesit (Andesite) & $1.7 \times 10^{2}-45 \times 10^{4}$ \\
\hline Basal ( Basalt) & $200-100000$ \\
\hline Gamping ( Limestone) & $500-10000$ \\
\hline Batu pasir ( Sandstone) & $200-8000$ \\
\hline Batu tulis ( Shales) & $20-2000$ \\
\hline Pasir ( Sand) & $1-1000$ \\
\hline Lempung ( Clay) & $1-100$ \\
\hline Air tanah ( Ground water) & $0.5-300$ \\
\hline Air asin ( Sea water) & 0.2 \\
\hline Magnetit ( Magnetite) & $0.01-1000$ \\
\hline Kerikil kering ( Dry gravel) & $600-10000$ \\
\hline Aluvium ( Alluvium) & $10-800$ \\
\hline Kerikil ( Gravel) & $100-600$ \\
\hline
\end{tabular}

\section{Hasil dan Pembahasan}

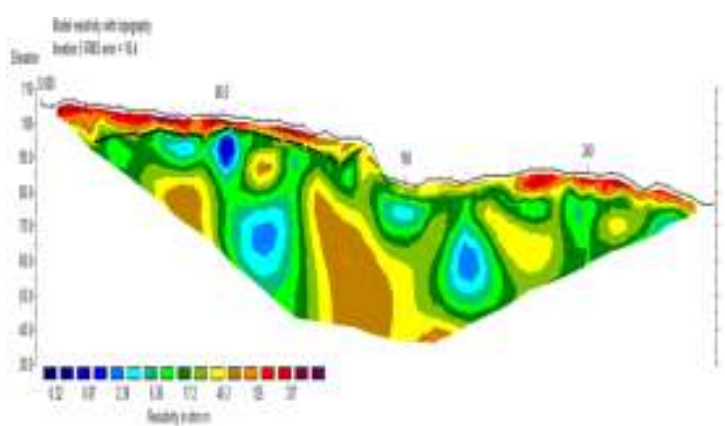

Gambar 1. Penampang resistivitas pada lokasi I

Hasil penampang resistivitas pada lokasi I menunjukkan geometri bidang gelincir, dengan kemiringan (slope) toporgafi bervariasi. Pada daerah tersebut dijumpai beberapa titik longsoran. Dari citra pada Gambar 1 terdapat nilai tahanan jenis dan jenis batuan sebagai berikut: pada bagian lapisan atas yang ditandai variasi warna warna hijau pucuk pisang ke warna merah diperoleh resistivitas $17,2 \Omega \mathrm{m}$ sampai 337 
$\Omega m$. Pada keadaan ini lapisan tanah diduga sebagai lapisan gamping pasiran yang biasanya merupakan lapisan lolos air (permeable). Selanjutnya, nilai resistivitas lapisan tanah dengan dari warna hijau tua ke hijau mudah memiliki rentanh dari 6,36 $\Omega \mathrm{m} \quad$ sampai $17,1 \quad \Omega \mathrm{m}$, yang diinterpretasikan sebagai lapisan kedap air atau inpermeable berupa lapisan lempung (clay).

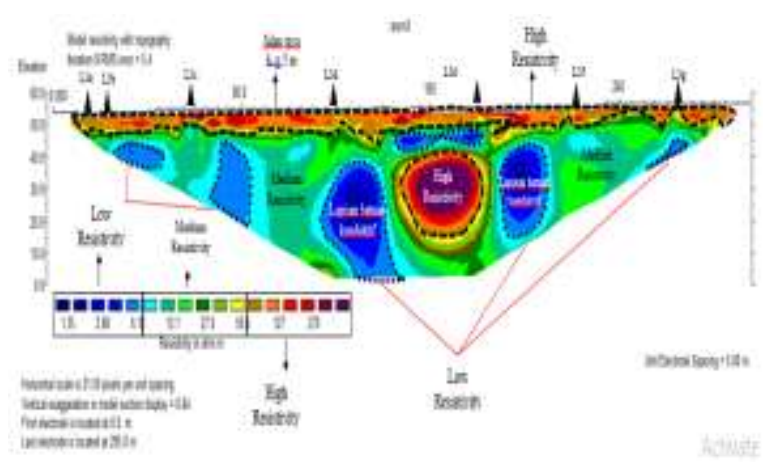

Gambar 2. Penampang resistivitas pada lokasi II

Selanjutnya pada lokasi II diperoleh penampang resistivitas yang diperoleh dapat diperlihatkan pada Gambar 2. Dalam rangka memudahkan pembacaan nilai resistivitas, pembacaan dibagi ke dalam 3 bagian yakni: bagian dengan nilai resistivitas rendah $<6,13 \Omega \mathrm{m}$, nilai resistivitas sedang dalam rentang $(6,13 \Omega \mathrm{m}$ $-59,4 \Omega \mathrm{m}$ ) dan nilai resistivitas tinggi ( > $59,4 \Omega \mathrm{m}$ ). Pada lapisan dengan nilai resistivitas rendah diduga terdiri atas batulempung yang kedap air. Selanjutnya, pada lapisan dengan nilai resistivitas sedang diduga terdiri dari lapisan batupasir yang bersifat lolos air. Kemudian pada lapisan dengan nilai resistivitas tinggi diduga sebagai batuan keras seperti batugamping dan basalt.

Pada lokasi III penampang resistivitas sebagaimana terlihat pada Gambar 3 terlihat adanya formasi berbentuk dyke yang biasanya merupakan tempat akumulasi air tanah, yang diduga merupakan material berupa batugamping.

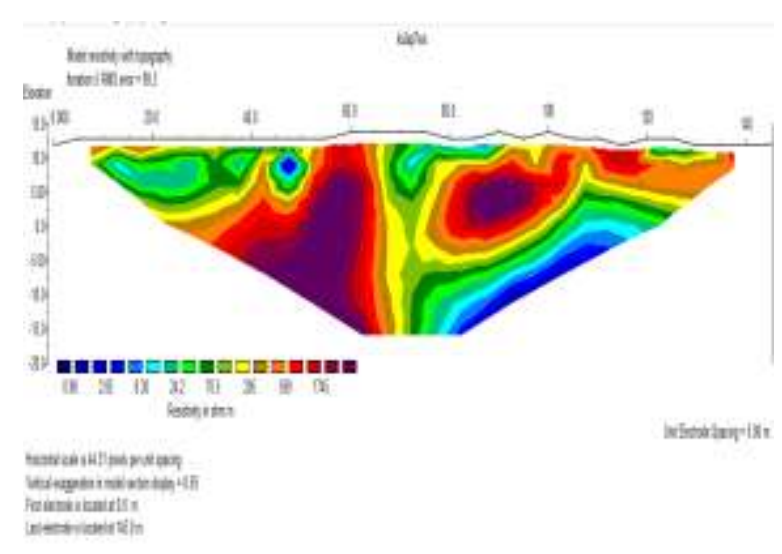

Gambar 3. Penampang resistivitas pada lokasi III

\section{Kesimpulan}

Dari akuisisi dan pengolahan data geolistrik tahanan jenis pada 3 lokasi yang berbeda, dapat disimpulkan bahwa:

1. Terdapat perbedaan material pada setiap lapisan tanah atau batuan, dengan nilai resistivitas yang bervariasi.

2. Diprediksi bahwa struktur perlapisan tanah pada umumnya berupa material lempung, pasir dan batugamping. Lapisan pasir dan lempung diprediksi terdapat pada lokasi kedua, tempat pengambilan data berupa lereng, ditemukan beberapa titik longsoran. Selanjutnya, diperkirakan terdapat struktur tanah berupa batugamping yang membentuk $d y k e$ di lokasi ketiga.

\section{Ucapan Terima Kasih}

Ucapan terima kasih ditujukan kepada LP2M Universitas Hasanuddin yang telah membantu pembiayaan penelitian melalui skema PDPA dan beberapa pihak yang telah membantu dalam akuisisi data di lapangan.

\section{Daftar Pustaka}

Kearey, P., Michael, B., Ian, H. 2002. An Introduction to Geophysical Exploration. Blackwell Science Ltd. London.

Loke, M.H. 2004. Electrical Immaging Surveys for Environmental and 
Engineering Studies; A Practical Guide to 2-D and 3-D Surveys.

Reynolds, J.M. 1997. An Introduction to Applied and Enviromental Geophysics. New York: John Wiley \& Sons.

Telford, W.M., Geldart, L.P. and Sheriff, R.E. 1990. Applied Geophysics, Second Edition. Cambridge University Press, United State of America.

Wijaya, Lean. 2009. Identifikasi Pencemaran Airtanah dengan Metode Geolistrik Di Wilayah Ngringo Jaten Karanganyar. Jurusan Fisika. Universitas Sebelas Maret. Surakarta. 